American Journal of Economics and Business Administration 2 (3): 330-338, 2010

ISSN 1945-5488

(C) 2010 Science Publications

\title{
Firm's Environmental Performance: A Review of Their Determinants
}

\author{
${ }^{1}$ Amir Hossein Montazer Hojat, ${ }^{2}$ Khalid Abdul Rahim and ${ }^{3}$ Lee Chin \\ ${ }^{1}$ Department of Economics, Faculty of Economics and Social Sciences, \\ Shahid Chamran University, Ahvaz, Iran \\ ${ }^{2}$ Institute of Agricultural and Food Policy Studies, Putra Infoport, \\ ${ }^{3}$ Faculty of Economics and Management, \\ University Putra Malaysia, 43300 Serdang, Selangor, Malaysia
}

\begin{abstract}
Problem statement: The role of environment in global economic development is vital since it is the life-support system providing sources of food and water, pleasant surroundings and sceneries and transportation lines. Firms' environmental performances are of high interest in worldwide environmental protection. Approach: Many factors affect firms' environmental performance. Some of these are of external origin while others are of the internal ones. Several empirical studies have sought to identify these factors. Most of the studies, however, had analyzed merely one of the determinants of the environmental performance neglecting the others. Based on a review of fifty related studies, this research identified and reviewed the effects of three major determinants of firms' environmental performance. Results: The results suggested that using marketbased instruments and command-and-control approach to control pollution does not and should not prevent other factors from being considered. Just complying with the regulations was not sufficient to ensure prevention of environmental degradation. Moreover, the public and private costs of these methods of environmental protection were significant. In this study also the effected of voluntary actions doing by Firms were analyzed. Our findings showed that it is still unclear whether or not these actions lead to an improvement in firms' environmental performance. Most previous studies on the effects on firms' environmental performances of voluntary actions were not unanimous. Conclusion: The study also considered the effects on firms' environmental performance of managerial attitudes. It followed that a logical development in the economic literature could be realized by analyzing the effects on firms' environmental performance of managerial attitudes. In addition, although firms' characteristics had been incorporated in the majority of relevant studies in the past, they present mixed conclusions. In fact, in order to make a proper policy, it is recommended that firms' environmental performance be comprehensively considered, that is together with its all determinants.
\end{abstract}

Keywords: Firms' environmental performance, government pressures, society pressure, market pressure, internal characteristics

\section{INTRODUCTION}

Many factors affect firms' environmental performance. Some of these have external origin such as government pressure, society and market pressure while others have internal origin in a form of as firms' characteristics and managers' attitudes. A firm's environmental performance is affected by three factors including government pressures, voluntary actions as an outcome of society and market pressure such as environmental management system and internal characteristics of the firm and managerial attitudes as depicted in Fig. 1. Environmental performance of firms, for example in their level of pollution abatement, could be affected by actions done voluntarily. The voluntary actions are those done by firms to reduce their pollution level even beyond the mandatory standards. Motives for these actions come from two different sources: market and society. Doonan et al. (2005) argued that the market pressures result from four sources: Investors, input providers, competitors and customers. They recognized community and Non-Governmental Organizations (NGO's) as sources of social pressures. In addition to the above factors, firm's environmental performance could also be affected by the government. The government regulates directly to make firms meet

Corresponding Author: Amir Hossein Montazer Hojat, Department of Economics, Faculty of Economics and Social Sciences, Shahid Chamran University, Ahvaz, Iran 
the mandatory standard and/or uses economic instruments to control pollution indirectly. The firms' environmental performance could likewise be influenced by internal characteristics including manager attitudes and firms' characteristics. Management attitudes to remove the pollution resulting from their operations affects firms' environmental performances. Moreover, firm characteristics such as size, age and ownership type could influence firm's environmental performance.

This study reviews existing application of economic instruments and command-and-control approaches as a usual policy to control firms' pollution by the government. Using recent studies we determine other factors which influence firms to reduce their pollution.

Environmental policy: Environmental policies have been based on Market-Based Instruments (MBI) and Command-And-Control (CAC) approaches. The market-based instruments rely on market factors and variations in prices for the public-and private-sector polluters to respond in a manner that help environmental protection or improvement. The "command and control" is a regulatory one. Environmental protection/improvement is the goal in this approach through setting limitations on discharge level of certain pollutants, limiting some activities to specific regions or periods of time and regulating processes or products.

In most industrial countries, the governments tend to employ the aforementioned instruments as their primary pollution control strategy dating back from the early ages of formulating environmental policy. Nevertheless, many countries have found regulatory instruments ineffective for attaining most pollution control goals since the cost of meeting strict environmental regulations has forming a significant proportion of the production cost.

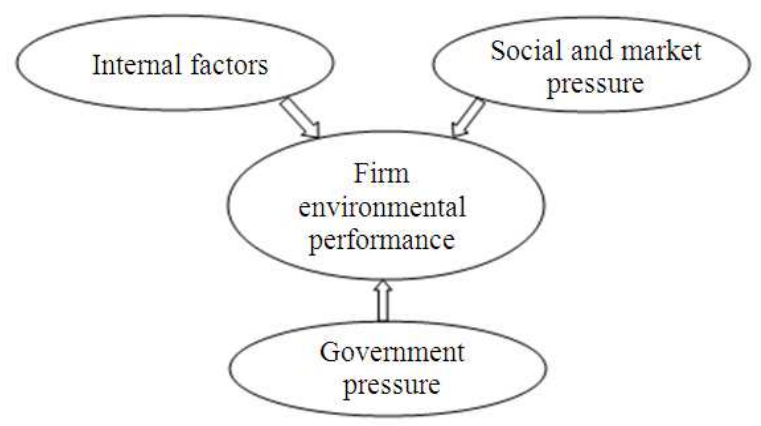

Fig. 1: Environmental performance determinants
Consequently, many governments are seeking alternative mechanisms giving the most cost-effective solution to the problem of pollution control. Such methods should not impose unreasonable financial pressures on firms and should not restrain economic growth.

An advantage of economic instruments over the regulatory ones is their potential for proving pollution control economically beneficial to firms and to reduce costs associated with pollution abatement. Furthermore, they could be used for a broad range of environmental issues and could create incentives and lead to effective implementation and enforcement. The major types of economic instruments applied to pollution controls are Pollution charges, Marketable permits, Subsidies and Deposit and refund systems.

Advantages and disadvantages: The theoretical advantages of economic instruments include:

- They provide firms with flexibility to react independently according to market prices so that they could meet environmental management goals at minimal costs

- They create a durable incentive for firms to decrease pollution, which in turn encourages them to use new technology facilities to treat their pollution as much as possible

- They enable firms to increase their revenue (in the case of charges) through financing abatement activities

- They welcome the development of existing industries and arrival of new ones more flexibly than the regulatory approach

The benefits coming from economic instruments help compensate the shortcomings of the regulatory approach, namely their economical inefficiency and unreasonable cost of execution. For instance, exclusive of their costs of pollution abatement, all firms are required to meet the same mandatory standard under the regulatory method. Thus, only the bigger sized firms would apply pollution control equipment: their cost of pollution control per unit of output is lower due to their higher amount of production. In the regulatory mechanism, there is no incentive to innovate in abatement technology. It creates slight financial incentive, if any, for firms to go beyond their control targets. In addition, compliance often is dependent upon the regulatory authorities' power in enforcing and the number of firms regulated. The larger number the more demanding is the task of appropriately enforcing the regulations. In comparison, economic instruments are 
more suitable for a greater number of point and nonpoint pollution sources. However, the economic instrument approach has its own shortcomings. The major ones are as follows:

- Since any polluter employs its own method, the impact on environmental quality of the economic approach is not as predictable as those of the regulatory approach

- If pollution charges are applied, some polluters may choose to pollute and to pay the incurring charge if the charge is not sufficiently high

- Normally, they call for some institutions to enforce and implement them suitably. This is the case particularly for charges and tradable permits

Another problem to be noted is that both regulators and firms have resisted the arrival of economic instruments. For instance, regulatory agencies, have opposed to the approach due to the low level of control over polluters that it grants them. On the other side, firms have objected to them since they may regard economic instruments as extra constraints (when they add to the existing regulations). For instance, the cost resulting from charges is normally higher than that from complying with regulations. Moreover, economic instruments often involved implementation requirements. To set prices for environmental resources and to estimate the degree of environmental damage are two major hindrances to the application of economic instruments. Several studies have demonstrated the outcomes of economic instruments and CAC in various countries. A study carried out by Kathuria (2006), seeks for policy instruments resulting in a drop in water pollution in Malaysia, Poland and Colombia. The results indicated that an overall betterment in environmental media is achievable through a combination of various instruments-standards, license fees, subsidies and charges-along with the necessary enforcement. Murty et al. (2006) for sugar industry of India, Jiang and Mckibbin (2002) for China, Goldar et al. (2001) for small factories in India, Dasgupta et al. (2001) for some industries in China, Hailu and Veeman (2000) for Canadian pulp and study industry and Khalid (1996) for palm oil mills in Malaysia, Bataineh (2006) for improving of competition in manufacturing companies, Salleh et al. (2007) for readiness in meeting globalization challenges, Nasir and Abdullah (2004) for accrual and cash flow measures investigated the effects of economic instruments on firm's environmental performance such as the level of pollution abatement.
Voluntary actions: Recent studies have revealed that just complying with the regulations is not sufficient to ensure prevention of environmental degradation and that the public and private costs of this method of environmental protection are considerable (Earnhart, 2004). In their study, Arimura et al. (2007) concluded that it is better that regulatory and voluntary approaches are used simultaneously. Zhang et al. (2008) expressed that firms' awareness of their consequences of pollution and their tendency to take voluntary actions such as Environmental Management System (EMS) are becoming more important. A voluntary action may be defined as follows.

Paton (2001) defined generally a voluntary environmental action as private or public sector efforts to improve environmental performance beyond existing legal requirements. Arimura et al. (2007) define a voluntary action as an environmental management system. They state that an EMS should include policy making, planning and implementation and review of the environmental policies. They argue that EMS helps firms decrease the environmental effects of their functions. However, Boudouropoulos and Arvanitoyannis (1998) argue that a management system needs firms register with ISO14000 standard institute. Sometimes, however, high cost of registration deters firms from registration. Even some firms may achieve good environmental performance without registration. Hence, it seems more suitable that the definition of voluntary action is not limited to EMS.

Regarding voluntary actions two points are of interest. First, why do voluntary actions undertaken by the firms and the second is why voluntary actions are expected to improve environmental performance. In addition to the findings of previous studies, there are several reasons why voluntary actions are carried out by the firms. According to social responsibility theory firms may utilize ethical decision making to keep safe their businesses by making decisions which permit government organizations to minimize their interaction with the firms (Kaliski, 2001). Hence, if a firm is proactive and follows the standards of pollution it may reduce its pollution even beyond the standard to become responsible in the society and shows its concerns that the public might also have; it could reduce the government organizations to inspect it for environmental behaviors. In this regard, a firm may emphasize voluntary actions or "self-regulation" rather than government inspection for protecting environment media. Doonan et al. (2005) argue the motives for voluntary actions could also be from market forces. Doonan et al. (2005) argued that the market pressures result from four sources: investors, input providers, competitors and customers. They 
recognized community and Non-Governmental Organizations (NGO's) as the sources of social pressures.

Regarding to why voluntary actions expected to improve environmental performance firstly, these actions help firms concentrate on environmental management objectives (King et al., 2005). Second, in some countries, the voluntary programs offered by government or other organizations provide firms with technical assistances such as workshops on reducing pollution. These help firms reach their environmental goals.

Some economic studies have examined the effects of non-regulatory factors on corporate environmental performance. Likewise, some empirical works have attempted to examine the environmental consequences of voluntary actions. The key question is whether or not the voluntary actions could lead to improvement in the firms' environmental performance. In other words, it is whether or not companies expending large sums of funds are useful means to improve their environmental performance. This question could be of interest also to regulatory authorities who make policy in each country in that a government hopes that these actions could assist regulatory mechanisms (Ammenberg et al. 2002). To answer this question, it is important that the voluntary actions are defined and indicators are selected to measure the firms' level of voluntary actions. Likewise, if voluntary actions are regarded as policy instruments, it is necessary to identify the connection between these actions and environmental performance. Thus, indicators should be specified to show firm's level of environmental performance.

In connection with the link between voluntary actions and environmental performance, previous studies have expressed that voluntary actions-even those without third-party monitoring-cause improvement in environmental performance (Khanna and Damon, 1999). However, other empirical studies have shown that involving in voluntary actions do not improve environmental performance (King and Lenox, 2000; Rivera and De Leon, 2004; Rivera et al., 2006). Thus, there are mixed results and many questions hence remain unanswered regarding the overall effects of voluntary actions as it is not yet well known if these programs are meeting their environmental targets.

A Meta study conducted by Nawrocka and Parker (2009), comprising a pool of 23 studies attempted to relate environmental performance and environmental management systems. The study revealed that previous studies had come up with mixed conclusions and had two-sided causes. First, there exists no clear understanding on what environmental performance is or how to evaluate it. Second, some ambiguity exists about why/how environmental management systems are anticipated to help performance. Consequently, it is vague whether there are mechanisms resulting in improvement characteristic-dependent, or they are anticipated to be the same for all firms. Arimura et al. (2007) analyzed the effects of voluntary actions on environmental performance. They defined the environmental performance as usage of natural resource such as fuel and water and generation of solid waste and wastewater effluent. They found firm's environmental performance to be dependent upon a set of voluntary actions such as adopting ISO14001 and publication of reports. They concluded that voluntary actions akin to ISO14001 reduce all the environmental impacts. Annandale et al. (2004) examined the effects of two voluntary environmental actions on the environmental performance of forty companies in Western Australia. They considered two voluntary actions including utilization of Environmental Management System (EMS) and Corporate Environmental Reporting (CER). They also considered some other factors which have effects on environmental performance. Their results show that, practically, the effects of EMS and CER are not as profound as are believed to be. Melnyk et al. (2003) examined the effects of three types of EMS: an informal system: a formal system that does not meet ISO 14001 standards and a formal system that meets ISO 14001 standards. According to their results, three types of EMS play significant role in reducing pollution. Thus it is preferable that voluntary actions are defined as various types of actions which are carried out by the firms voluntarily.

Internal characteristics: Firms differ from each other in their internal characteristics such as their age, size, financial status and type of ownership. Also, the managers' attitudes for environmental programs are different between firms. An increasing number of studies are devoted to the evaluation of the effects of firm's characteristics on firm's performance. Most of the researches have focused on demonstrating the effects of the characteristics on efficiency and productivity and some of them have sought to show their impact on environmental performance. We review the factors to show that such differences between the firms affect their environmental performance.

Age and size effects: In light of their access to more resources, bigger firms are often at a more advanced stage in connection with environmental issues. For many years, they have been utilizing environmental 
management, as a constituent of their environmental strategies. On the other hand, firms of smaller size have known to offer more reactivity to environmental issues (Roy and Vezina, 2001). Anton et al. (2004) claimed that firm's environmental performance could be affected by its characteristics, for instance its age and size. Several causes have been found for this behavior: normally, the bigger a firm the more significant is its influence on the environment. Furthermore, bigger firms often have a better knowledge of how to deal with multiple stakeholder pressures due to their longer experience. Moreover, bigger financial and human resources are more available to bigger firms than to the others. On the contrary, small to medium-sized firms have restricted access to the resources. They tend to pay much less to reduce their pollution level (Kasim, 2009).

Empirical studies have also suggested that improved environmental performance typically comes at the cost of small increases in operating costs (Berman and Bui, 2001; Shadbegian and Gray, 2003). However, these costs are unlikely to be uniform across various firms for several reasons: First, operational and administrative economies of scale in pollution abatement allow large firms to enhance their environmental performance at a lower price (per unit of output) than those for smaller ones (Dean et al., 1998). Second, improving environmental performance costs firms with longer operational experience less than those with lesser experience (Dean et al., 1998). Also, according to legitimate theory, firms can be surviving by being legitimized in the eyes of the public. Specially, large sized firms are more visible in the eyes of the public because the bigger a firm the more significant is its influence on the environment. Hence, they may seek to improve their environmental performance increasingly.

Arimura et al. (2007) showed that the effect of firm size and age on environmental performance is positive and significant. Khanna et al. (2009) concluded that the larger sized firms would have more resources to carry out pollution abatement activities than those of the smaller ones. Zhang et al. (2008) indicated that increasing firm size ends in better environmental performance. Nakamura et al. (2001) argued that firm size is an important factor in engaging firms with environmental plans. Berman and Bui (2001) and Shadbegian and Gray (2003) stated that improving the environmental performance commonly increases firms' costs. However, these costs are not likely to be the same among various firms: firstly, only large firms could improve their environmental performance since pollution abatement activities costs them less (Dean et al., 1998;
Pashigian, 1976); secondly, firms with further operation experience bear lesser costs for improving their environmental performance than those with lesser experience (Dean et al., 1998). Shadbegian and Gray (2006) argued that large-sized firms gain economies of scale in providing technical assistance to abate their emissions further. Additionally, they showed that the older firms are expected to be less productive and are likely to find it more costly to achieve a given level of environmental performance. Likewise, Roberts (1992) concluded that younger firms are more active than older ones in protecting the environment. Cordeiro et al. (2009) and Elsayed (2006) argued that firm size will determine firm's organizational capacity in adopting appropriate environmental performance. Gunningham (2002) demonstrated that small and medium-sized enterprises do not have adequate resources and skills to engage with the environmental activities their business practices. Dao and Ofor (2008) found firm size to be a factor helping firm to reduce their material waste. Also, the age of the firms affect their environmental performance (Melnyk et al., 2003).

While several studies like those aforementioned alleged that there is strong evidence that large firms are more likely to participate in environmental issues, empirical studies conducted by some people, for example, Lyon and Maxwell (2002) and Khanna (2001) imply that where all firms are large, firm size is not a very important factor for improvement in environmental performance.

Ownership type effects: Many studies have sought to find out whether the type of ownership could affect firm's environmental performance. In other words, are publicly-owned firms cleaner than privately-owned firms? Also, are the firms with foreign owners more polluting than those with domestic owners?

Type of ownership influences firm's tendency for pursuing an environment protection and abating its air pollution and effluent discharges (Earnhart and Lizal, 2007; Cole et al., 2005). Some empirical studies have analyzed the influence of ownership status on firm's environmental performance. Among them are the studies conducted by Bluffstone (1999) and Earnhart and Lizal (2006) for some economies in Central and Eastern Europe and those performed by Cordeiro et al. (2009); Wang and Wheeler (2003; 2005) and Wang et al. (2003) for China.

Earnhart and Lizal (2007) examined the effect of ownership structure on firms' environmental performance. They concluded that an increase in state ownership leads to improvement in environmental performance via allowing further investment in 
pollution abatement. Conversely, Pargal and Wheeler (1996) showed that a change from private to public of ownership status causes a rise in firm's water pollution in Indonesia. They found public firms to be 5.4 times more water polluting than the private ones. Cole et al. (2008) showed that firms with foreign owners have wider access to newer technologies and also foreign training or experience which helps them reduce their fuel usage. Hence, in comparison with the domestic firms, the foreign ones tend to increase their use of electricity which is a cleaner source of energy with lesser pollution in Ghanaian manufacturing firms.

The results of the study performed by Nakamura et al. (2001) showed that the ownership status, as a firm's characteristic, affects its environmental performance. This study showed that foreign owners have lesser attention to the social welfare and therefore few invest in environmental issues. The results of this study were similar to those of the study conducted by DeCanio (1994).

Managerial attitudes effects: Managers play a significant role in adjusting employee skills, incentive and capability with organizational systems, structures and processes that achieve capabilities at the organizational level (Teece et al. 1997). Theory of Reasoned Action suggests that a person's behavioral intention depends on the person's attitude. Therefore, if a person intends to do a behavior then it is likely that the person will do it. If the manager believes in reducing pollution, then he will lead to improve the firm's environmental performance.

Many empirical studies have examined the effects on efficiency of managerial attitudes, profitability, level of production (Henriques and Sadorsky, 1995; 1996). Nonetheless, few studies, have analyzed the influence on environmental performance of managerial attitudes in a statistical sense (Ervin et al., 2008). Cordano and Frieze (2000) show that managerial attitude towards pollution reduction has a positive relationship with abatement activities. Henriques and Sadorsky (2007) argue that firms with managers who are aware of the effects of the use of natural resource on the environment are more likely to improve their environmental performance and to pay more attention to the environmental issues. Khanna et al. (2007) state that the higher the manager's knowledge of the fact that the environment is a significant issue the larger is the number of environmental actions a firm takes. Hence, manager's knowledge of environmental issues is a factor that, when accompanied with high degree of motivation give companies the ability to concurrently enhance their environmental performance and several competitiveness dimensions (Alberti et al., 2000). Chinander (2001) argues that manager's dealing with environmental issues may affect employees' realization of the relation between their actions and environmental consequences. Alberini and Segerson (2002) show the significance of attitudes of environmental manager to the achievement of environmental aims.

\section{CONCLUSION}

This study surveys the literature on firms' environmental performance from three aspects: government pressures, market and society pressure (through voluntary actions as their outcome) and internal characteristics. Commonly, using MBI and $\mathrm{CAC}$ approaches have had essential role in protecting environmental media against further deterioration. All firms have to meet the same mandatory standard under the regulatory method. Also in the regulatory mechanism, innovation in abatement technology is not attractive. It creates slight financial incentive, if any, for firms to go beyond their control targets. In addition, compliance often is dependent upon the regulatory authorities' power in enforcement and the number of firms regulated. The larger that number the more demanding is the task of appropriately enforcing the regulations. Regarding market instruments shortcomings, only the big-sized firms would apply pollution control equipment due to its costs. Also, to set prices for environmental resources and to estimate the degree of environmental damage are two major hindrances to the application of economic instruments. Several studies have demonstrated, MBI versus CAC are more suitable for a greater number of point and nonpoint pollution sources. Using those approaches to control pollution does not and should not prevent considering other factors. Just complying with the regulations is not sufficient to ensure prevention of environmental degradation and that the public and private costs of this method of environmental protection are considerable. Firms' awareness of their consequences of pollution and their tendency to take voluntary actions are becoming more important. Hence, recent studies in environmental area argue that it is better that regulatory and voluntary approaches are used simultaneously. This study shows that despite many empirical studies related to market instruments, few studies have considered other factors, especially the effect of managerial attitudes on environmental performance. It follows that a logical development in the economic literature could be realized through analyzing the effects of managerial attitudes on environmental performance. Noting to the literature, it 
could be deduced that the bearing on firm's environmental performance of managerial attitudes have not been yet appreciated well. In fact, numerous studies have extensively focused on the relationship between environmental performance and firm characteristics. However, the environmental effect of managerial attitudes has remained an open question. However, in the majority of the studies where firm characteristics have been incorporated mixed conclusions have resulted.

\section{REFERENCES}

Alberini, A. and K. Segerson, 2002. Assessing voluntary programs to improve environmental quality. Environ. Resour. Econ., 22: 157-184. DOI: 10.1023/A:1015519116167

Alberti, M., M. Caini, A. Calabrese and D. Rossi, 2000. Evaluation of the costs and benefits of an environmental management system. Int. J. Prod. Res., 38: 4455-4466. DOI: 10.1080/00207540050205226

Ammenberg, J., O. Hjelm and P. Quotes, 2002. The connection between environmental management systems and continual environmental performance improvements. Corp. Environ. Strat., 9:183-192. DOI: 10.1016/S10667938(02)00011-8

Annandale, D., A. Morrison-Saunders and G. Bouma, 2004. The impact of voluntary environmental protection instruments on company environmental performance. Bus. Strat. Environ., 13: 1-12. DOI: 10.1002/bse. 390

Anton, W.R.Q., G. Deltas and M. Khanna, 2004. Incentives for environmental self-regulation and implications for environmental performance. J. Environ. Econ. Manage., 48: 632-654. DOI: 10.1016/j.jeem.2003.06.003

Arimura, T.H., A. Hibiki and H. Katayama, 2007. Is a voluntary approach an effective environmental policy? A case for environmental management system. J. Environ. Econ. Manage., 55: 281-295. http://pweb.sophia.ac.jp/arimura/cv/working/RFFDP-07-31.pdf

Bataineh, T.M., 2006. The role of an environmental management in improving of competition in manufacturing companies. J. Soc. Sci., 2: 48-53. DOI: $10.3844 /$ jssp.2006.48.53

Berman, E. and L.T.M. Bui, 2001. Environmental regulation and productivity: Evidence from oil refineries. Rev. Econ. Stat., 83: 498-510. DOI: 10.1162/00346530152480144

Bluffstone, R., 1999. Are the costs of pollution abatement lower in Central and Eastern Europe? Evidence from Lithuania. Environ. Dev. Econ., 44: 449-470. DOI: 10.1017/S1355770X99000285
Boudouropoulos, I.D. and I.S. Arvanitoyannis, 1998. Current state and advances in the implementation of ISO 14000 by the food industry. Comparison of ISO 14000-9000 to other environmental programs. Trends Food Sci. Technol., 9: 395-408. DOI: 10.1016/S0924-2244(99)00008-4

Chinander, K.R., 2001. Aligning accountability and awareness for perceived environmental performance in operations. Prod. Operat. Manage., 10: 276-291. DOI: $10.1111 /$ j.19375956.2001.tb00375.x

Cole, M.A., R.J.R. Elliott and E. Strobl, 2008. The environmental performance of firms: the role of foreign ownership, training and experience. Ecol. Econ., 65: 538-546. DOI: 10.1016/j.ecolecon.2007.07.025

Cole, M.A., R.J.R. Elliott and K. Shimamoto, 2005. Industrial characteristics, environmental regulations and air pollution: An analysis of the UK manufacturing sector. J. Environ. Econ. Manage., 50:121-143. DOI: 10.1016/j.jeem.2004.08.001

Cordano, M., H.I. Frieze, 2000. Pollution reduction preferences of U.S. environmental managers: Appling Ajzen's theory of planned behavior. Acad. Manage. J., 43: 627-641. doi:10.1016/j.jeem.2004.08.001

Cordeiro, J.J., Q. Zhu and J. Sarkis, 2009. International and domestic pressures and Chinese organizational responses to greening. Acad. Manage. Proc. 2009: 16.

Dao, M.A. and G. Ofor, 2008. Determinants of firm compliance to environmental laws: A case study of Vietnam. AEJ Eur. J., 8: 91-112. DOI: 10.1007/s10308-008-0186-y

Dasgupta, S., B. Laplante, N. Mamingi and H. Wang, 2001. Analysis inspections, pollution prices and environmental performance: Evidence from China. Ecol. Econ., 36: 487-498. DOI: 10.1016/S09218009(00)00249-4

Dean, T.J., R.L. Brown and C.E. Bamford, 1998. Differences in large and small firm responses to environmental context: strategic implications from a comparative analysis of business formations. J. Strat. Manage., 19: 709-728. DOI: 10.1002/(SICI)1097-0266(199808)19:8<709::AIDSMJ966>3.0.CO;2-9

DeCanio, S.J., 1994. Energy Efficiency and Managerial Performance: Improving Profitability while Reducing Greenhouse Gas Emissions. In: Global Climate Change and Public Policy, Feldman, D.L. (Ed.). Nelson-Hall, Chicago, ISBN: 9780830413416, pp: 86-101. 
Doonan, J., P. Lanoie and B. Laplante, 2005. Determinants of environmental performance in the Canadian pulp and paper industry: An assessment from inside the industry. Ecol. Econ., 55: 73-84. http://ideas.repec.org/a/eee/ecolec/v55y2005i1p7384.html

Earnhart, D. and L. Lizal, 2006. Effects of ownership and financial performance on corporate environmental performance. J. Comparat. Econ., 34: 111-129. DOI: 10.1016/j.jce.2005.11.007

Earnhart, D. and L. Lizal, 2007. Direct and indirect effects of ownership on firm-level environmental performance. Eastern Eur. Econ., 45: 66-87. http://ideas.repec.org/a/mes/eaeuec/v45y2007i4p66 $-87 . h t m l$

Earnhart, D., 2004. Time is money: Improved valuation of time and transportation costs. Environ. Resour. Econ., 29: 159-190. DOI: 10.1023/B:EARE.0000044604.77782.6b

Elsayed, K., 2006. Reexamining the expected effect of available resources and firm size on firm environmental orientation: An empirical study of UK firms. J. Bus. Eth., 65: 297-308. DOI: 10.1007/s10551-006-6402-z

Ervin, D., J. Wu, T. Wirkkala, M. Khanna and C. Jones, 2008. Voluntary' business environmental management: Role of regulation, market forces and management values. Policy Stud. J., 35: 751-772.

Goldar, B., S. Misra and B. Mukherji, 2001. Water pollution abatement cost function: Methodological issues and an application to small-scale factories in an industrial estate in India. Environ. Dev. Econ., 6: 103-122.

http://ideas.repec.org/a/cup/endeec/v6y2001i01p10 3-122_00.html

Gunningham, N., 2002. UK: Leaders and Laggards: Next Generation Environmental Regulation. 1st Edn., Greenleaf Publishing, Sheffield, ISBN: 10: 1874719489, pp: 224.

Hailu, A. and T.S. Veeman, 2000. Environmentally sensitive productivity analysis of the Canadian pulp and paper industry, 1959-1994: An input distance function approach. J. Environ. Econ. Manage., 40: 251-274. DOI: 10.1006/jeem.2000.1124

Henriques, I. and P. Sadorsky, 1995. The determinants of firms that formulate environmental plans. Res. Corporate Soc. Perform. Policy, 1: 67-97.

Henriques, I. and P. Sadorsky, 1996. The determinants of an environmentally responsive firm: An empirical approach. J. Environ. Econ. Manage., 30: 386-395. DOI: 10.1006/jeem.1996.0026
Henriques, I. and P. Sadorsky, 2007. Environmental Management Systems and Practices: An International Perspective. In: Environmental Policy and Corporate Behavior, Johnstone, N. (Ed.). Edward Elgar Publishing, Inc., Northampton, MA., ISBN: 13: 978-1847200327, pp: 34-87.

Jiang, T. and W.J. Mckibbin, 2002. Assessment of Chinas pollution levy system: An equilibrium pollution approach. Environ. Dev. Econ., 7: 75-105. DOI: $10.1017 / \mathrm{S} 1355770 \mathrm{X} 02000050$

Kaliski, B., 2001. Social Responsibility and Organizational Ethics: Encyclopedia of Business and Finance Macmillan Reference. 2nd Edn., Macmillan Reference New York, USA., pp: 791.

Kasim, A., 2009. Managerial attitudes towards environmental management among small and medium hotels in Kuala Lumpur. J. Sustain. Tourism, 17: 709-725. DOI: 10.1080/09669580902928468

Kathuria, V., 2006. Controlling water pollution in developing and transition countries-lessons from three successful cases. J. Environ. Manage., 78: 405-426. PMID: 16171929

Khalid, A.R., 1996. Why pollution standard are preferred by industries: Pragmatism and rentseeking behavior. Environmentalist, 16: 49-53. DOI: 10.1007/BF01325614

Khanna, M. and L.A. Damon, 1999. EPA's voluntary 33/50 program: Impact on toxic releases and economic performance of firms. J. Environ. Econ. Manage., 37: 1-25. DOI: 10.1006/jeem.1998.1057

Khanna, M., 2001. Non-mandatory approaches to environmental protection. J. Econ. Surv., 15: 291-324. DOI: 10.1111/1467-6419.00141

Khanna, M., P. Koss, C. Jones and D. Ervin, 2007. Motivations for voluntary environmental management. Policy Stud. J., 35: 751-772. DOI: 10.1111/j.1541-0072.2007.00246.x

Khanna, M., G. Deltas and D. Harrington, 2009. Adoption of pollution prevention techniques: The role of management systems and regulatory pressures. Environ. Resour. Econ., 44: 85-106. http://ideas.repec.org/a/kap/enreec/v44y2009i1p85106.html

King, A.A. and M.J. Lenox, 2000. Industry selfregulation without sanctions: The chemical industry's responsible care program. Acad. Manage. J., 43: 698-716. http://www.jstor.org/stable/1556362

King, A.A., M.J. Lenox and A. Terlaak, 2005. The strategic use of decentralized institutions; exploring certification with the ISO 14001 management standard. Acad. Manage. J., 48: 1091-1106. http://faculty.darden.virginia.edu/LenoxM/pdf/iso_ amj.pdf 
Lyon, T.P. and J.W. Maxwell, 2002. voluntary approaches to environmental regulation: A survey. Kelley School of Business Indiana University Bloomington. http://webuser.bus.umich.edu/tplyon/VERChap3.PDF Melnyk, S.A., R.P. Sroufe and R. Calantone, 2003. Assessing the impact of environmental management systems on corporate and environmental performance. J. Operat. Manage., 21: 329-351. DOI: 10.1016/S0272-6963(02)00109-2

Murty, M.N., S. Kumar and M. Paul, 2006. Environmental regulation, productive efficiency and cost of pollution abatement: A case study of the sugar industry in India. J. Environ. Manage., 79: 1-9. PMID: 16181728

Nakamura, M., T. Takahashi and I. Vertinsky, 2001. Why Japanese firms choose to certify: A study of managerial responses to environmental issues. J. Environ. Econ. Manage., 42: 23-52. DOI: 10.1006/jeem.2000.1148

Nasir, N.M. and S.N. Abdullah, 2004. Information provided by accrual and cash flow measures in determining firms? performance: Malaysian evidence. Am. J. Applied Sci., 1: 64-70. DOI: 10.3844/ajassp.2004.64.70

Nawrocka, D. and T. Paker, 2009. Finding the connection: Environmental management systems and environmental performance. J. Cleaner Prod., 17: 601-607. DOI: 10.1016/j.jclepro.2008.10.003

Pargal, S. and D. Wheeler, 1996. Informal regulation of industrial pollution in developing countries: Evidence from Indonesia. J. Politic. Econ., 104: 1314-1327. http://www.jstor.org/pss/2138941

Pashigian, P.B., 1976. Consequences and causes of public ownership of urban transit facilities. J. Politic. Econ., 84: 1239-1259. http://www.jstor.org/stable/1831276

Paton, B., 2001. Voluntary Environmental Initiatives and Sustainable Industry. In: Voluntary Environmental Industry Agreements: Process, Practice and Future Use, Brink, P.T. (Ed.). Greenleaf Publishing Ltd., Sheffield, UK., ISBN: 10: 1874719411, pp: 37-49.

Rivera, J. and P. De Leon and C. Koerber, 2006. Is greener whiter yet. The sustainable slopes program after five years. Policy Stud. J., 34: 195-221. DOI: 10.1111/j.1541-0072.2006.00166.x

Rivera, J. and P. De Leon, 2004. Is greener whiter? Voluntary environmental performance of western ski areas. Policy Stud. J., 32: 417-437. DOI: 10.1111/j.1541-0072.2004.00073.x
Roberts, R.W., 1992. Determinants of corporate social responsibility disclosure: An application of stakeholder theory. Account. Org. Soc., 17: 595-612. http://ideas.repec.org/a/eee/aosoci/v17y1992i6p595 $-612 . h t m l$

Roy, M.J. and R. Vezina, 2001. Environmental performance as a basis for competitive strategy: Opportunities and threats. Corp. Environ. Strat., 8: 339-347. DOI: 10.1016/S1066-7938(01)00118-X

Salleh, A., R.C. Rose, N. Kumar and L.C. Peng, 2007. Readiness in meeting globalization challenges: A case of accounting firms in Malaysia. J. Soc. Sci., 3: 176-184. DOI: 10.3844/jssp.2007.176.184

Shadbegian, R.J. and W.B. Gray, 2003. What determines environmental performance at paper mills. The roles of abatement spending, regulation and efficiency. Topics Econ. Anal. Policy, 3: 1-19. http://ideas.repec.org/p/nev/wpaper/wp200303.html

Shadbegian, R. and B. Gray, 2006. Assessing multidimensional performance: Environmental and economic outcomes. J. Prod. Anal., 26: 213-234. DOI: $10.1007 / \mathrm{s} 11123-006-0017-3$

Teece, D.J., G. Pisano and A. Shuen, 1997. Dynamic capabilities and strategic management. Strat. Manage. $\quad$ J., $\quad$ 18: 509-533. http://www.fearp.usp.br/fava/pdf/dynamic.pdf

Wang, H. and D. Wheeler, 2003. Equilibrium pollution and economic development in china. Environ. Dev. Econ., 8: 451-466. DOI: 10.1017/S1355770X030024X

Wang, H. and D. Wheeler, 2005. Financial incentives and endogenous enforcement in china's pollution levy system. J. Environ. Econ. Manage., 49: 174-196. http://ideas.repec.org/a/eee/jeeman/v49y2005i1p17 4-196.html

Wang, H., N. Mamingi, B. Laplante and S. Dasgupta, 2003. Incomplete enforcement of pollution regulation: Bargaining power of Chinese factories. Environ. Resour. Econ., 24: 245-262. DOI: 10.1023/A:1022936506398

Zhang, B., B. Jun, Z. Yuan, J. Ge and L. Beibei et al., 2008. Why do firm engage in environmental management? An empirical study in China. J. Cleaner Prod., 16: 1036-1045. DOI: 10.1016/j.jclepro.2007.06.016 